\title{
Association between dust particulate and occupational rhinitis among basement parking lot workers in Jakarta
}

\author{
Niken Lestari Poerbonegoro*, Setyawati Budiningsih", Rina Metalapa** \\ * Department of Ear Nose Throat-Head and Neck Surgery, \\ **Department of Community Medicine, Faculty of Medicine Universitas Indonesia/ \\ Dr. Cipto Mangunkusumo Hospital \\ Jakarta
}

\begin{abstract}
Background: Jakarta municipal government estimates that at least $70 \%$ of Jakarta air pollution comes from traffic and vehicles. The prevalence of occupational rhinitis increases in such polluted environment. History of atopic disease and smoking habit might aggravate this condition. Purpose: To determine the association between dust particulate matter exposure and occupational rhinitis among basement parking lot workers in Jakarta. Methods: A cross-sectional study was performed on 57 workers from December 2014 until March 2015. Questionnaires on nasal symptoms and eosinophil counts by nasal mucosal scrapings were collected before and after working-hours to evaluate occupational rhinitis. Level of dust particulate matter was measured using high volume air sampler, and calculated by gravimetric method. Results: Three workers were diagnosed with occupational rhinitis (5.2\%). Level of dust particulate matter was below permitted level in studied basement parking lots. There was no significant association between occupational rhinitis and working period (OR 0.5 [95\% CI 0.43 to 5.85], $\mathrm{p}=1.000$ ) and workplace (OR 435 [95\% CI $=0.37-51.37], \mathrm{p}=0.255$ ). Increased eosinophil level was associated with the history of atopic disease (OR 23.33 [95\% CI $=2.40-224.62], \mathrm{p}=0.001$ but not associated with smoking habit (OR $0.13[95 \% \mathrm{CI}=0.22-7.71], \mathrm{p}=0.575)$. Conclusion: There was no significant association between dust particulate matter exposure and occupational rhinitis among basement parking lot workers. Despite the low level of dust particulate matter exposure, occupational rhinitis did occur.
\end{abstract}

Keywords: atopic, dust particulate matter exposure, eosinophil, occupational rhinitis.

\section{ABSTRAK}

Latar belakang: Pemerintah DKI Jakarta memperkirakan sekitar 70\% polusi udara di Jakarta berasal dari lalu lintas dan kendaraan bermotor. Prevalensi Rinitis Akibat Kerja (RAK) cenderung meningkat pada lingkungan berpolusi. Riwayat atopi dan kebiasaan merokok dapat memperberat penyakit tersebut. Tujuan: mengetahui hubungan pajanan partikulat debu terhadap RAK pada pekerja area parkir basement di Jakarta. Metode: Studi potong lintang dilakukan terhadap 57 pekerja dari Desember 2014 sampai Maret 2015. Pengisian kuesioner gejala hidung dan hitung jumlah eosinofil kerokan mukosa hidung dilakukan sebelum dan sesudah jam kerja untuk evaluasi RAK. Kadar partikulat debu diukur dengan High Volume Air Sampler lalu dikalkulasi dengan metode gravimetrik. Hasil: Didapatkan 3 orang pekerja dengan diagnosis RAK (5,2\%). Kadar pajanan partikulat debu di lokasi studi dibawah nilai ambang batas yang diizinkan. Tidak terdapat hubungan bermakna antara RAK dengan lama bekerja (OR 0,5 [95\% CI 0,43- 5,85], $p=1,000)$ dan tempat kerja (OR 435 [95\%CI=0,37$51,37], p=0,255)$. Terdapat hubungan yang bermakna antara peningkatan kadar eosinofil dan riwayat atopi (OR 23,33 [95\%CI=2,40-224,62], $p=0,001)$, tetapi hubungan tidak bermakna ditemukan antara peningkatan kadar eosinophil dan kebiasaan merokok (OR 0,13 [95\% CI=0,22-7,71], p=0,575). Kesimpulan: Tidak terdapat hubungan bermakna antara pajanan partikulat debu dan RAK pada pekerja area parkir basement. Pada kadar partikulat debu rendah, ternyata ditemukan pekerja dengan RAK.

Kata kunci: atopi, pajanan partikulat debu, eosinofil, rinitis akibat kerja.

Alamat korespondensi: Dr. Niken L Poerbonegoro, Sp.T.H.T.K.L.(K), Departemen Ilmu Kesehatan Telinga Hidung Tenggorok-Bedah Kepala Leher, Fakultas Kedokteran Universitas Indonesia. Rumah Sakit Dr. Cipto Mangunkusumo, Jakarta. Jl. Diponegoro No.71, Salemba Jakarta Pusat. 


\section{INTRODUCTION}

Dust particulate matter in the workplace is part of indoor air pollutants that may cause health disturbance among the workers, mostly are respiratory problems. All workers could be affected, but several subjects are more prone, those are older-age workers, workers with history of atopic diseases, or smoking habit. A study showed the association between indoor air pollutants and the incidence of occupational rhinitis. This study showed that particulate matter, carbon monoxides and nitric dioxides were major indoor air pollutants. ${ }^{1}$

Work related rhinitis is classified into occupational rhinitis and work exacerbated rhinitis. Occupational rhinitis is caused directly by particular substances encountered in the workplace. ${ }^{2}$ Symptoms are manifested from immunologic and non-immunologic mechanisms. Immunoglobulin E-mediated reaction is the basic of immunologic mechanism in occupational rhinitis. Contact of particular allergen from the workplace in workers who are previously sensitized stimulates mast cell degranulation. Inflammatory mediators, like histamine, leukotriene, tryptase, and cytokines, are released, causing increased capillary permeability, increased glandular secretion and stimulating sensory nerve of the nasal mucosa. These mediators also act as chemo-attractant to inflammatory cells, which are responsible for the late phase of allergic reaction. ${ }^{2,3}$ On the other hand, nonimmunologic mechanism is considered as a neurogenic response to various irritant agents. Following sensory nerves stimulation, mediators like substance $P$ and neuropeptides are released causing similar effect of increased capillary permeability. ${ }^{2,4}$

Occupational rhinitis could become a burden for workers and companies. Symptoms may affect working performances, resulting in the decrease of working time and efficiency, as well as the increase of healthcare cost. It is estimated that $15 \%$ of workers worldwide suffered from occupational rhinitis. Industrial workers are the most affected, reach up to $48 \%$, followed approximately $29 \%$ by administrative workers. The prevalence of occupational rhinitis in population of workers exposed to biological agent was reported around 2-87\%, while the number of those who were exposed to gas or irritant was $1-48 \%$. Hospital and health care workers are also at risk. $^{2}$

Major risk factors for occupational rhinitis are substance exposure at the workplace, and history of atopic diseases. Studies had shown the relation of atopic and increased risk of specific sensitization to variety of high molecular weight (HMW) agents. A study reported that atopic, identified by positive skin test results, increased to $6.5 \%$ after 1 year of working and $8.2 \%$ after 2 years. Other known risk factors are level of exposure, duration of exposure, age, and smoking habit. However, controversial results were found on the relation between smoking and occupational rhinitis. ${ }^{2,4}$

Symptoms such as sneezing, rhinorrhea, or nasal congestion, which are related to working, and absent when not in workplace, should be suspected as an occupational rhinitis. However, establishing diagnosis only by history taking is not recommended due to its impact on socio-economic condition of workers. Nasal provocation test is the gold standard method for diagnosing occupational rhinitis. Yet, it is a high-cost examination and standardized instrument are not easily available. Alternative and simple methods are taken into consideration, particularly for research. Those are allergy skin test, test for nasal patency (peak nasal inspiratory flowmetry, rhinomanometry, acoustic rhinometry), and eosinophil counts. ${ }^{2,3,4}$ Arjana et $\mathrm{al}^{5}$ used nasal eosinophil count by mucosal scrapping to detect allergic rhinitis. Its sensitivity was reported $70 \%$ and specificity $94 \%$. In allergic rhinitis, increased of nasal eosinophil count is detected in 1-2 hours after exposure, which reaches its peak after 6-8 hours. 
Pollutants are substances in environment that adversely affect environment or living organisms within. Air pollutants mosty are chemical products from moving vehicles, industrial materials and waste, electricity power station, or household utensils. Major air pollutants, that tend to affect respiratory system, are sulfur dioxide $\left(\mathrm{SO}_{2}\right)$, nitric dioxide $\left(\mathrm{SO}_{2}\right)$, particulates, and ozone $\left(\mathrm{O}_{3}\right)$. Particulate matter or dust particulate matter is often referred as inhalable particles, can be found around roadway (vehicular emission) or industries. ${ }^{3,6,7}$

Jakarta government estimated that at least $70 \%$ of Jakarta air pollution is from roadways and vehicles. Furthermore, in a modern-developing city like Jakarta, highrise buildings with compact parking lots are typical features. This study aimed to: 1) get the level of dust particulate matter in the basement parking lots, 2) identify the proportion of basement parking lot workers who suffered occupational rhinitis, and 3) find the association between dust particulate matter exposure and occupational rhinitis among basement parking lot workers.

\section{METHODS}

A cross-sectional study was performed in Jakarta from December 2014 to March 2015. Fifty-seven workers from two basement parking lots (Sofyan Betawi Hotel and Budhi Asih Hospital) were included. Inclusion criteria were: a) fully working in basement area, b) aged 20-40 years, c) had worked for more than one year, and d) willing to follow research procedures. Exclusion criteria were: a) suffering from severe pulmonary disease (i.e. tuberculosis, bronchitis, and chronic obstructive pulmonary disease), and b) suffering from common cold while sampling.

Level of dust particulate matter exposure was measured from 2 locations. There was 8 points of measurements collected from these 2 locations. Measurements were done using high volume air sampler, then calculated by gravimetric method.

All subjects were assessed by filled-in questionnaires about nasal symptoms on the first visit. Working period was determined by counted years in the observed place. Working unit was the place where the subject worked daily, classified as directly-exposed and indirectly-exposed. Smoking habit and history of atopic diseases were identified by a Yes/No question to the subjects. Nasal mucosa sample was collected by scrapping the inferior turbinate mucosa using Rhinoprobe instrument, then fixated with Hansel reagent. Eosinophil count was performed under microscope with 100x magnification, then classified using Naclerio's criteria: a) negative: if no eosinophil/10 fields, b) +1 : for $1-5$ eosinophil/10 fields, c) +2 : for 6-15 eosinophil/10 fields, d) +3 : for 16-20 eosinophil/10 fields, and e) +4 : for $>20$ eosinophil $/ 10$ fields. ${ }^{8}$

Fill-in questionnaires and nasal eosinophil count were done again at second visit, 4 hours after working time. Workers with presence/worsening of nasal symptoms and $\geq 20 \%$ increased eosinophil count were diagnosed as occupational rhinitis.

Data with categorical scale e.g. sex, level of education, smoking habit, and working duration were shown as frequency distribution and percentage. Age, working period, and level of dust particulate matter were presented as mean and standard deviation. ShapiroWilks test was used to analyze the data and showed abnormality $(\mathrm{p}<0.05)$.

Association between each group was analyzed by Spearman test.

\section{RESULT}

Fifty-seven workers were enrolled in this study, 37 of them were aged $30-40$ year old. Subjects were dominated with 45 male workers. The obtained proportional number 
of workers who had worked for $\leq 4$ years and $>4$ years, respectively 29 and 28 workers. None of the workers wore Personal Protective Equipment (PPE) while working.

Table 1 shows characteristics based on age, sex, working period, and usage of PPE while working. Level of dust particulate matter exposure in all studied divisions varied, but still below the government permitted threshold of $10 \mathrm{mg} / \mathrm{m}^{3} .{ }^{9}$ In Sofyan Betawi Hotel, level of dust particulate matter either at indirect-exposed or direct-exposed division was $1.61 \mathrm{mg} / \mathrm{m}^{3}$. In Budhi Asih Hospital, the dust particulate matter levels at 3 indirect-exposed divisions respectively were $1.88,1.88$, and $2.16 \mathrm{mg} / \mathrm{m}^{3}$, while at 3 direct-exposed divisions were 4.16, 4.22, and $8.11 \mathrm{mg} / \mathrm{m}^{3}$. Level of dust particulate matter in 8 working divisions (based on exposure category) are described in table 2.

Only 3 workers were diagnosed with occupational rhinitis, based on $\geq 20 \%$ increased eosinophil count. Two of them had worked for less than or equal to 4 years. There were no significant association between occupational rhinitis with working periods (OR 0.5; $\mathrm{p}=1.000)$. Based on exposure category, two workers with occupational rhinitis were from indirect-exposed division and there were no significant association between occupational rhinitis with working divisions (OR 4.35; $\mathrm{p}=0.255$ ). The association between occupational rhinitis with working period and working division are shown in table 3.

Six workers showed increased eosinophil count. Five of them had a history of atopic disease. Increased eosinophil level was significantly associated with history of atopic disease (OR 23.33 [95\% CI=2.40-224.62], $\mathrm{p}=0.001$ ). Four workers with increased of eosinophil count had smoking habit. Yet there was no significant association between the increased eosinophil count and smoking habit

Table 1. Subject characteristics

\begin{tabular}{lll}
\hline Characteristics & $\mathbf{n}=\mathbf{5 7}$ & $\mathbf{\%}$ \\
\hline Age (years) & & \\
$20-29$ & 20 & 35,1 \\
$30-40$ & 37 & 64,9 \\
& $32(6,357)$ & \\
Mean (SD) & $33(20-40)$ & \\
Median (Range) & & 78,9 \\
\hline Sex & 45 & 21,1 \\
Male & 12 & \\
Female & 29 & 50,9 \\
\hline Working period & 28 & 49,1 \\
$\leq 4$ years & $6,42(5,308)$ & \\
$>4$ years & $4(1-20)$ & 100 \\
Mean (SD) & & 0 \\
Median (Range) & \multicolumn{2}{l}{} \\
\hline Personal Protective Equipment (PPE) & 57 & \\
No & 0 & \\
Yes & & \\
\hline
\end{tabular}


Table 2. Level of dust particulate matter in working divisions (based on exposure category)

\begin{tabular}{|c|c|c|c|c|}
\hline Work division & $\begin{array}{l}\text { Level of dust } \\
\text { particulate matter } \\
\left(\mathrm{mg} / \mathrm{m}^{3}\right)\end{array}$ & $\begin{array}{l}\text { Permitted } \\
\text { threshold } \\
\left(\mathrm{mg} / \mathrm{m}^{3}\right)\end{array}$ & Location & Exposure \\
\hline Engineering & 1.61 & 10 & Sofyan Betawi Hotel & Indirect \\
\hline Security & 1.61 & 10 & Sofyan Betawi Hotel & Direct \\
\hline Cooperatives B1 & 1.88 & 10 & Budhi Asih Hospital & Indirect \\
\hline Canteen B1 & 1.88 & 10 & Budhi Asih Hospital & Indirect \\
\hline Technician B1 & 2.16 & 10 & Budhi Asih Hospital & Indirect \\
\hline Parking B2 & 4.16 & 10 & Budhi Asih Hospital & Direct \\
\hline Cashier B2 & 4.22 & 10 & Budhi Asih Hospital & Direct \\
\hline Construction B2 & 8.11 & 10 & Budhi Asih Hospital & Direct \\
\hline
\end{tabular}

Table 3. Association between occupational rhinitis with working period and working division

\begin{tabular}{lllll}
\hline Variable & $\begin{array}{l}\text { Occupational } \\
\text { rhinitis } \\
(\mathbf{n}=\mathbf{3})\end{array}$ & $\begin{array}{l}\text { Non } \\
\text { occupational } \\
\text { rhinitis (n=54) }\end{array}$ & p & OR (95\%CI) \\
\hline Working period & 1 & 27 & 1.000 & $0.5(0.43-5.85)$ \\
$>4$ years & 2 & 27 & & \\
$\leq 4$ years & 1 & & 0.255 & $4.35(0.37-51.37)$ \\
Working division & 2 & 37 & & \\
Direct-exposed & 17 & & & \\
Indirect-exposed & 1 & & & \\
\hline
\end{tabular}

Table 4. Association of increased eosinophil counts with smoking habit and history of atopic disease

\begin{tabular}{|c|c|c|c|c|}
\hline \multirow{2}{*}{ Variable } & \multicolumn{2}{|c|}{$\underline{\text { Increase of eosinophil level }}$} & \multirow[t]{2}{*}{$\mathbf{p}$} & \multirow{2}{*}{ OR $(95 \% C I)$} \\
\hline & Yes $(n=6)$ & No $(n=51)$ & & \\
\hline \multicolumn{5}{|l|}{$\begin{array}{l}\text { History of } \\
\text { atopic disease }\end{array}$} \\
\hline Yes & 5 & 9 & 0.001 & $23.22(2.40-224.62)$ \\
\hline No & 1 & 42 & & \\
\hline \multicolumn{5}{|l|}{ Smoking habit } \\
\hline Yes & 4 & 31 & 0.575 & $0.13(0.22-7.71)$ \\
\hline No & 2 & 20 & & \\
\hline
\end{tabular}

(OR $0.13[95 \% \mathrm{CI}=0.22-7.71], \mathrm{p}=0.575)$. The association between increased eosinophil counts with history of atopic disease and smoking habit are described in table 4.

\section{DISCUSSION}

In this study, the working area was categorized into indirect and direct-exposed division. Level of dust particulate matter exposures in direct-exposed divisions tend to be higher than indirect-exposed divisions, but still did not exceed the permitted government threshold $\left(10 \mathrm{mg} / \mathrm{m}^{3}\right) .{ }^{9}$ This finding indeed showed that the company had followed the regulation, that is to provide a safe working environment for their workers. Good ventilation system was applied at the 
basement, aimed to bring in fresh air from outside, dilute pollutants, filter and deliver good quality of air to the workers at the basement. One study mentioned that poor ventilation rate had been associated with health impacts. ${ }^{10}$ Stenberg et $\mathrm{al}^{11}$ found that low ventilation rate had a strong evidence to increase Sick Building Syndrome (SBS) symptoms among 4943 office workers in Northern Sweden.

We found 3 of 57 workers (5.2\%) diagnosed with occupational rhinitis. This result was relatively low compared to other studies. Anggraini et a ${ }^{12}$ found $27.8 \%$ workers from a chemical factory suffered from occupational rhinitis, with dust and irritant gas as the responsible agents. Few factors might influence our result. First, we did not use nasal provocation test, which is the gold standard test, due to unavailability issue. Diagnosis of occupational rhinitis then, was established by the presence of worsened symptoms and increased eosinophil counts, which were less sensitive than the gold standard. Second, we did not control other exposures outside and inside working places that might exaggerate or affect eosinophil counts in nasal mucosa.

Statistically, we did not find significant association between dust particulate matter exposure and occupational rhinitis. The low level of dust particulate matter exposure that we found probably affect the incidence of occupational rhinitis. In addition, insignificant finding might be caused by unevenly distribution of workers in the direct and indirect-exposed units. In our opinion, we should do further analysis on those other factors, such as personal protective equipment (PPE) application, other particulate matters, and irritants within the workplace. These factors probably play important roles in the occurrence of occupational rhinitis in this study. Further studies with normal distribution of samples and more accurate diagnostic methods might meet the unanswered questions.
Interestingly, we found a significant association between eosinophils count and atopy among workers. A study by Vimercati et $\mathrm{al}^{13}$ supported our finding. Their study compared allergy between exposed and non-exposed group, with a clear definition of exposure to air pollution for at least $80 \%$ of working time ( 7 hours a day, for 5 days). They found significantly higher percentage of allergic subjects in the exposed group. Whether allergy plays a role in the development of occupational disease, or vice versa i.e. traffic pollution induces allergic respiratory disease, still requires further study.

Despite the low dust particulate matter exposure and the insignificant association between dust particulate matter exposure and occupational rhinitis, there were 5.2\% of workers suffered from occupational rhinitis. This finding is indeed clinically important. Even in a relatively safe working environment, this study had identified workers with occupational rhinitis. Those workers were prone workers. In terms of health status, those workers should undergo appropriate treatment consists of avoidance /environment control and medications. They should be assigned to a more suitable working location within the company based on their health profiles. Surprisingly, we found negligence from both the company and the workers in applying personal protective equipment (PPE). Good supervision should be implemented regarding this PPE matter. Lastly, regular surveillance for workers confirmed with occupational rhinitis must be implemented to prevent further deterioration, or occurrence of occupational asthma. Occupational disease is one entity that can be prevented.

In conclusion, we were able to identify basement parking lot workers who suffered with occupational rhinitis, even though it was not associated with dust particulate matter exposure. 


\section{REFERENCES}

1. Sendra N, Kuhuwael FG, Akil A, Arfandy RB. Dampak pajanan debu kayu terhadap kadar eosinofil kerokan mukosa hidung pekerja penggergaji kayu. [Laporan Penelitian]. Fakultas Kedokteran Universitas Hasanudin. Makassar: 2010

2. Moscato G, Vandenplas O, Van Wijk RG, Malo JL, Quirce S, Walusiak J, et al. Position paper: Occupational Rhinitis. Allergy. 2008; 63: 969-80

3. Bousquet J, Khaltaev N, Cruz AA, Denburg J, Fokkens WJ, Togias A, et al. Allergic Rhinitis and its Impact on Asthma (ARIA) 2008. Allergy. 2008; 63: 8-160

4. Sublett JW, Bernstein DI. Occupational Rhinitis. Immunology and Allergy Clinics of North America. 2011; 31: 787-96

5. Arjana IM, Rianto BU, Sudarman K. Eosinofil usapan mukosa hidung kajian terhadap validitas sebagai kriteria diagnostik rhinitis alergi. ORLI. 2001; 31(4): 41-7

6. Peden DB. Air pollution in asthma: effect of pollutants on airway inflammation. Ann Allergy Asthma Immunol. 2001; 87: $12-7$

7. Seaton A, Godden D, MacNee W, Donaldson K. Particulate air pollution and health effect. The Lancet. 1995; 345 : $176-8$

8. Jacobsen L, Niggemann B, Dreborg S, Ferdousi HA, Halken S, Host A, et al. Specific immunotherapy has long-term preventive effect of seasonal and perennial asthma: 10-years follow-up on the PAT study. Allergy. 2007; 62: 943-8
9. Peraturan Menteri Tenaga Kerja dan Transmigrasi Nomor 13/MEN/X/2011 tentang Nilai Ambang Batas (NAB) Faktor Fisika dan Kimia di Tempat Kerja.

10. Allen JG, Bernstein A, Xiadong C, Eitland ES, Flanigan S, Gokhale M, et al. The 9 Foundations of a Healthy Building. USA: Harvard T.H. Chan School of Public Health; 2016. Available full text from:http://forhealth.org/Harvard.Building E vidence_for_Health.the 9_Foundations. pdf

11. Stenberg B, Eriksson N, Hogg J, Sundell J, Wall S. The Sick Building Syndrome (SBS) in office workers: A case-referent study of personal, psychosocial and building-related risk indicators. Int J Epidemiol. 1994; 23 : 1190-7

12. Anggraini D. Prevalensi Rinitis Akibat Kerja dan Faktor Risiko yang Berhubungan : Studi pada Pekerja yang Terpajan Debu dan Gas Iritan di PT.X tahun 2008. SpTHTKL. [thesis]. Jakarta: Universitas Indonesia; 2008

13. Vimercati L, Gatti MF, Baldassarre A, Nettis E, Favia N, Palma M, et al. Occupational exposure to urban air pollution and allergic disease. Int. J. Environ. Res. Public Health. 20151; 12: 12977-87 